\title{
The European Union's Attitude towards Russia between Values and Interests
}

\author{
Asst. Prof. Dr. Armağan Gözkaman (Beykent University, Turkey)
}

\begin{abstract}
The study will focus on the European Union's attitude towards Russia by taking into consideration a dilemma: The European Union (EU) wants to uphold its values and principles while endeavoring to maximize its interests. In the post-Cold War period, Moscow's policy choices have often been problematic for the Europeans. In the period following the Ukrainian conflict, the analysis of the relations between the two "strategic partners" is more difficult than ever. At least three reasons underlie this difficulty. First, the EU is notoriously incapable of reaching a common position on how to deal with the Russian problem. Second, trade is an important factor for the relations between the EU and Russia where oil occupies a significant place. Third, Russia has also a signification position vis-à-vis the EU as a powerful actor of international relations.
\end{abstract}

\section{Introduction}

Russia is a very important partner for the European Union (EU). It is also a very difficult one. At present, the problem of Ukraine made the balance between Brussels and Moscow all the more delicate. Russia began a military operation after the Ukrainian president had fled his country. In mid-March 2014, a referendum was held in Crimea with the remit of secession from Ukraine. 97\% of the voters supported Russian sovereignty over the peninsula. The EU, together with the USA, reacted quickly by depicting the referendum as a sham. The annexation of Crimea and Sebastopol to Russian Federation and the latter's continuous involvement in the crisis have become problematic issues for the relations between the EU and Russia.

The EU needs to uphold its values and confront the latter whenever necessary. Because Russia is a crucial actor of international relations, the Union feels the necessity to carry on good relations with it. Nevertheless, that is easier said than done. There are at least three reasons that underlie the current stalemate. The existence of twolevel relations between the EU and Russia is one of them (1). The fact that the EU member states conduct differing policies towards Russia is another point that merits attention (2). In addition, the European Union's Common Foreign and Security Policy, established with the entry into force of the Treaty of Maastricht in 1993, has not been adequate for the EU members to build up a unified foreign policy towards Russia.

\section{Relations between the European Union and Russia: A Two-Level Game}

The EU has adopted some policy lines that form the basis of its relations with Russia after the collapse of the Soviet Union. It is important to remember that 1990 s were the time period when the European continent underwent profound political changes. Back then, the European Union's (EU) agenda was remarked by designing the post-communist transformation process with a western template (Timmins, 2004). In the first half of the decade, the Technical Assistance to the Commonwealth of Independent States (TACIS) preceded the Partnership and Co-operation Agreement (PCA). The latter's ratification, however, could only take place after Russia had put an end to its military action in Chechnya in 1997, three years after the beginning of its intervention in the region.

Chechnya was not the only source of discord in EU-Russia relations. The perspective of membership given to the countries in the Central and Eastern Europe was a further blow for Moscow because of economic and political reasons. The Balkan crisis had a negative effect on the relations between the two sides as well (Timmins, 2004). However, these issues have not run counter to the adoption of a Common Strategy on Russia in 1999. The strategy, despite its late adoption by the EU members, increased the coherence and efficiency of EU actions in Russia (Delcour, 2005). The fact that 19 agreements have been signed between Russia and the EU since 1998 -covering a wide range of political and economic matters- is also noteworthy (European Commission).

A study on the EU-Russia relations will be incomplete if the bilateral relations between Moscow and the European capitals are not taken into consideration. That the European capitals have differing attitudes -resulting in various policies- towards Moscow is a fact. Many EU member states have strong political and economic relations with Russia that are even depicted as "strategic" or "special" partnerships specified in legal frameworks (David et al., 2011). This held especially true for the big states. In the case of Germany, for instance, the prioritization of national interests over the European ones has been criticized on many occasions. If Germany has done much more than the other EU member states in order to promote the EU policies on Russia, she has also done much to undermine them (Timmins, 2011). With regard to the United Kingdom, although political relations with Russia have been "less than special" the economic relations have been strong (David, 2011). Over the years, Spain has developed good economic relations with Russia in accordance with her national interests. She may 
follow "further a path of strict national interest assessment" as the motivation for the European integration has been fading away (Simao, 2011).

Some smaller states have also very close relations with Russia. Greece is among the examples that can be cited. She enjoys excellent relations in accordance with the "traditional friendly relations of the two peoples" that endured for centuries (Christou, 2011). Despite the lack of leadership and credibility in the case of Benelux countries, Netherlands has important commercial relations with Russia especially in the field of energy. Belgium could "punch above its weight" thanks to her being home to NATO and to the EU on the one hand, and her hosting frequent high-level visits from third countries on the other (Casier, 2011). These states had frequent bilateral summits with Russia resulting in important agreements that touched upon the key sectors such as energy and trade and that did not exclude the fields of security and culture (David et al., 2011).

\section{Russia: An Unavoidable Trading Partner for the EU}

The importance of Russia for the EU member states originates from a number of factors. Economy is one of them. The Russian market, despite the weaknesses generated by the macroeconomic problems, is still attractive for the European companies. As shown by the Figure 1, the EU's export to Russia almost doubled over the last decade. From 2005 to 2008 , a steady growth rate can be observed. The recession that hit Russian economy and the subsequent measures taken by Moscow explain why the trade volume decreases in 2009 (European Commission, 2013b). Then again, the trade between the two sides gained momentum to reach the highest level in 2012 and tended to decline afterwards.

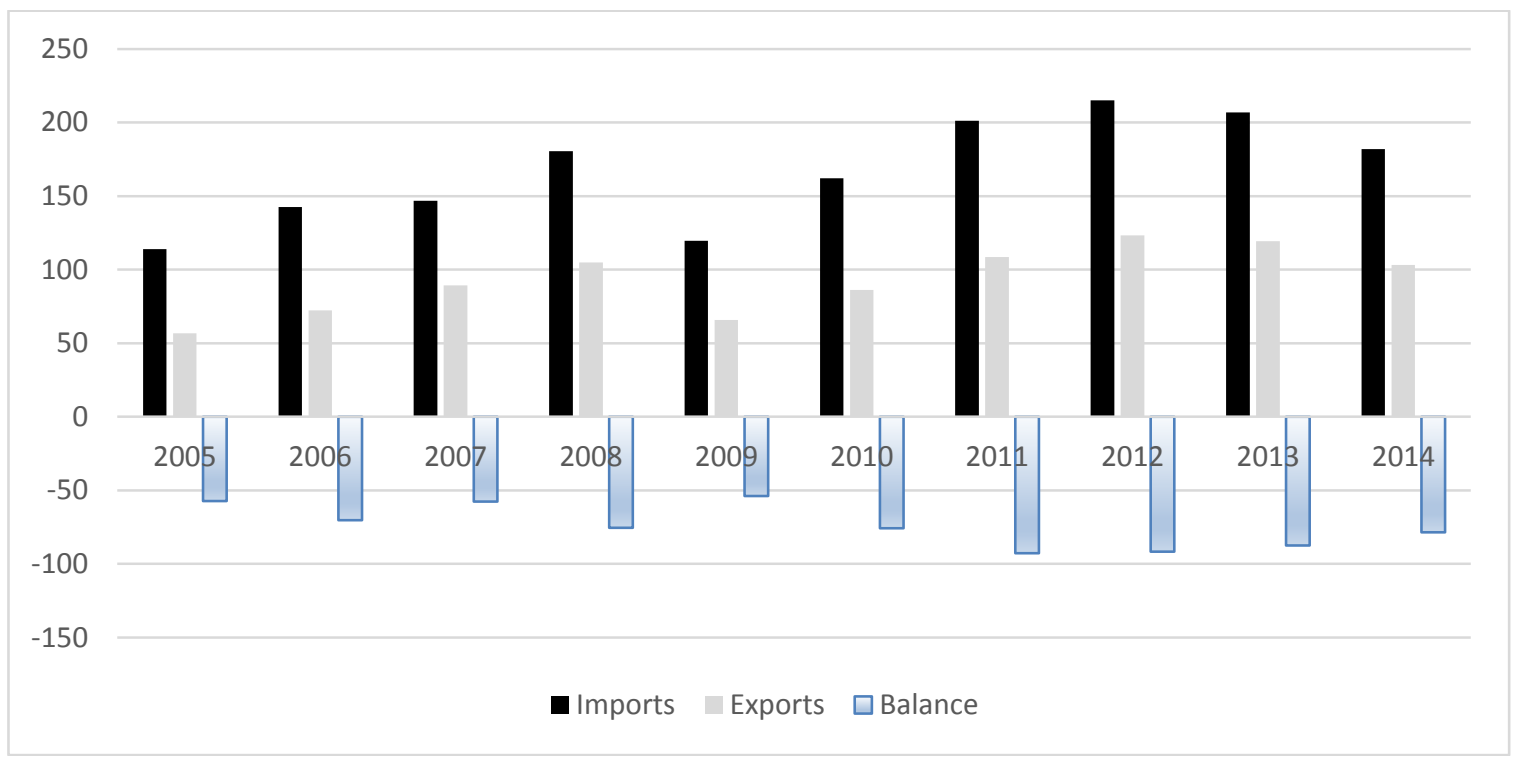

Figure 1: European Union, Trade with Russia, billion Euros (European Commission Directorate-General for Trade)

One can also highlight the place that Russia and the European Union hold in each other's trade: Russia has the third rank in the EU's trade with the outside world. The EU, for its part, holds the first position in Russia's foreign trade activities. Moreover, the EU is the biggest investor in Russia. Estimations suggest that around two thirds of foreign direct investment stocks in Russia originate from the EU member states (European Commission).

Indeed, fossil fuels are the decisive item in the relations between European capitals and Moscow. Russia is the main energy supplier of the European Union, and the EU provides a unified market to Russia. In this context, both sides have agreed to set up mechanisms to ensure security of supply and energy efficiency. The EU-Russia Energy Dialogue is one of them. Established in October 2000 with the objective of enabling progress for partnership, the initiative constituted the first example of an energy dialogue with a third party (European Commission, 2011). In February 2011, the European Commission and the Russian government went further by agreeing to build up a long-term perspective for their relations in the energy sector through the Common Understanding on the Preparation of the Roadmap of the EU-Russia Energy Cooperation until 2050 which stipulated the necessity to

"concentrate on an analysis of different scenarios and their impact on EU-Russia energy relations, look into their consequences for the energy sectors, elaborate long-term opportunities and risks of the overall energy supply and demand situation and investigate the potential for long-term cooperation in the field of energy." (European Commission, 2013a). 
Thanks to the statement above, there is no need to spill much ink to explain the reasons why the EU and Russia have signed the roadmap. The emphasis on the long-term cooperation reveals the concern to ensure the energy supply. At this point, one can legitimately maintain that the seller is in an advantageous position vis-à-vis the buyer -and that the mere possession of the energy resource bestows the owner with a power over the one that needs it. Thus, there is simultaneously an importer for whom the security is linked to the energy supply guaranteed by the market and an exporter for whom energy security is an integral part of a power strategy (Laïdi, 2008). That oil and natural gas constitute a significant factor in the EU-Russia relations is plain to see.

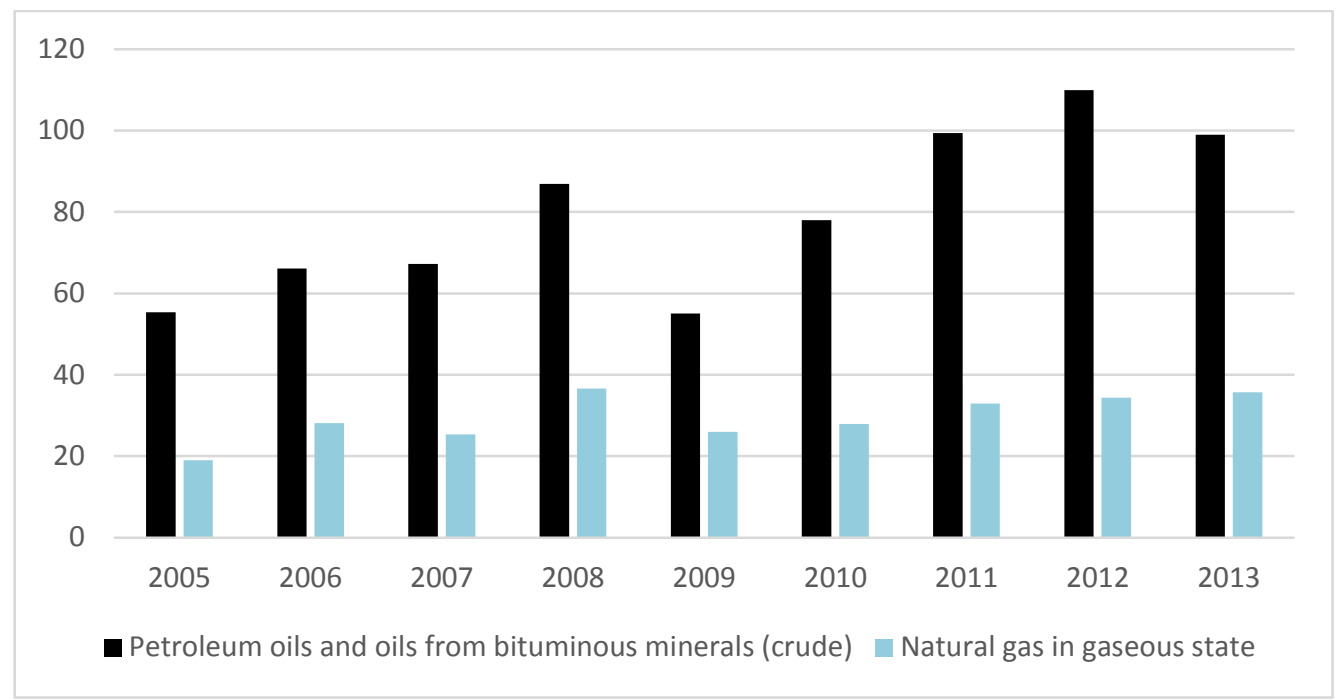

Figure 2: EU-28 Imports of Energy Products 2005-2013, billions of Euros Source: Eurostat

Figure 2 shows that the volume of fossil fuel trade between the two sides is also significant. The oil imported by the then-27 members of the EU and Croatia reached an approximate total of 110 billion Euros in 2012, to beat a record. The same year, they also paid 34,4 billion Euros for Russian natural gas. These amounts are all the more meaningful when they are evaluated together with the data represented by the Figure 3 below. Because the Russian currency lost 35\% of its value between 2008 and January 2009 (Maternovsky, 2009), the EU payments for Russian oil and natural gas in 2009 were limited to 55 and 26 billion Euros consecutively. Yet, the same year, the decrease of European demand to Russian natural gas is low (it falls from $37,6 \%$ in 2008 to $33 \%$ in 2009) whereas an increase of the Russian share in European crude oil purchase is observed.

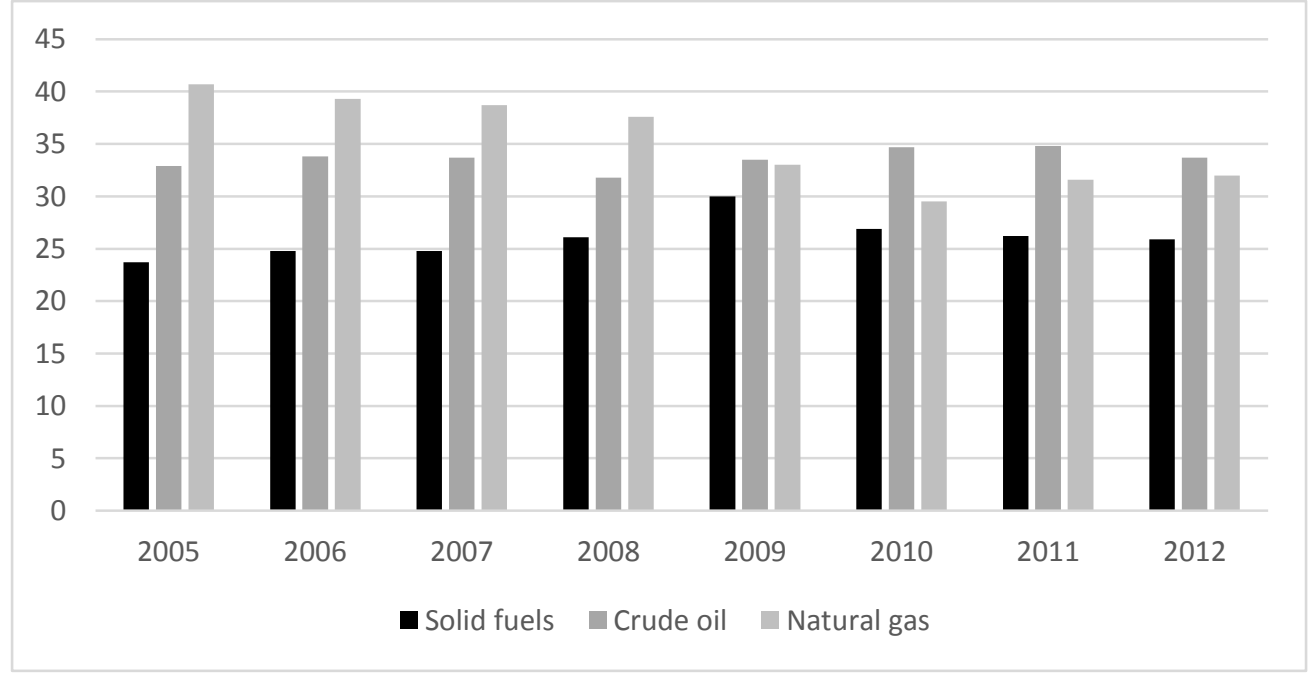

Figure 3: Russia's Share (\%) in the EU-28 Imports of Solid Fuels, Crude Oil and Natural Gas Source: Eurostat, 2014

\section{Russia: A Powerful International Actor with Its Own Agenda}

The EU endeavored to de-escalate the crisis in Ukraine by political and economic instruments. It has called on all sides to maintain dialogue for Ukraine's unity and territorial integrity. It also requested Russia to withdraw its troops back to the legal bases stipulated in the Agreement on the Status and Conditions of the Black Sea Fleet of 1997 (Council of the European Union, 2014). As a reaction to the illegal annexation of Crimea by Russia and the Russian involvement in the destabilization of Ukraine, the EU has agreed upon a variety of restrictive measures. 
Some of them are diplomatic, such as the cancellation of the EU-Russia summit and the support to the suspension of negotiations on Russia's OECD membership perspective. Some are of restrictive nature, including asset freezes and visa bans. The sanctions also include prohibitions on imports, investment, tourism services and exports (European Union Newsroom). Because the EU continues to condemn the above-mentioned illegal annexation, it "remains committed to fully implement its non-recognition policy" (Council of the European Union, 2015).

Yet, the question "How far the EU can go towards its objective to see the Ukrainian conflict resolved?" does not leave much room for optimism. As seen in the previous section, the member states are not able to establish and implement a common strategy towards Russia and the EU's dependency on this country is high. The Ukrainian case reveals the EU's capabilities and deficiencies, along with the time and determination that will be necessary for dealing with it (Suremain, 2014). In addition, Moscow is definitely a key actor in the international relations due to its membership of the United Nations Security Council and its potential to make a qualitative change in the international issues. Its cooperation in global issues is highly valued; and the Europeans cannot neglect this value while adopting policies towards Russia.

This strong position gives Russia some possibility to play by its own rules. Obviously, Kremlin does not have a serious concern to align itself with the European Union's principles or priorities. Vladimir Putin has been calling into question the decades-long European security system through revisionist politics (Grand, 2014), possibly in line with his earlier projects (Thom, 2014; Lefort, 2014). At this point, it is also important to remember that the compatibility between the EU's and Russia's interests is very low and that they share very little in their policies (Haukkala, 2015; Makarychev, 2014). This may be linked, among other factors, to the difference of both sides' conceptions of Europe. Against the wider Europe vision that reflects the idea of the continent centered on the European Union, Moscow upholds the vision of a greater Europe that postulates a multipolar continent with no single ideology (Sakwa, 2015).

In this dire context, one way out of the crisis can be to establish a dialogue between Russia and the EU on solid -and realistic- grounds by taking into consideration the Russian interests and sensibilities (Tchernega, 2014). Back in 2012, Pascal Boniface had affirmed that Russia was rather a partner than an ally. A similar argument can be brought up, by saying that Russia will never be on the same line with the European Union, but she can be suitable for working together. A process of 'give and take' seems more plausible to bring an end to Russia's support to the destabilization of Ukraine. After all, Russia will not benefit from the prolongation of the crisis which will lead to an environment of antagonism similar to the one witnessed in the post-Second World War period (Andréani, 2014).

\section{Concluding Remarks}

The recent crisis in Ukraine has been a hard blow for EU-Russia relations. The EU has reacted to Russia's move in Ukraine, with limited instruments indeed. So far, its retaliations have not had a tangible effect upon Kremlin's political choices. One cannot expect a change in the situation any time soon.

For the EU to make a progress in the resolution of the conflict, a two-level action is necessary. The unified and coordinated approach at the EU level must be echoed at the national levels as well. The alignment of national interests with the European ones can bear fruit, especially in the presence of a determination to combine economic and political components for dealing with Russia.

To recommend the diversification of energy suppliers seems also commonsensical. Indeed, such a project may not be realized quickly. Nevertheless, the high dependence on Russian fossil fuels weakens the European prospects to ease antagonism with Moscow. Thus, the diversification efforts must be conceived as a 'political investment' for the future.

There is room for optimism anyway. In fact, the resolution of the crisis will benefit both Russia and the West. In the long run, neither of them will benefit from a new context of Cold War. Hence, an active involvement of the EU (along with its member states) in accordance with a viable political project can facilitate the process of crisis resolution.

\section{References}

- Andréani, 2014. "Poutine et l’Ukraine”, Commentaire, 146, p. 291.

- Boniface, 2012. “La Russie n'Est pas Une Alliée, mais Elle Peut Etre Un Partenaire”, Le Monde, http://www.lemonde.fr/idees/article/2012/06/25/la-russie-n-est-pas-une-alliee-mais-elle-peut-etre-unepartenaire 1723976 3232.html\# ((Accessed 01.06.2015).

- Casier, 2011. "The Bilateral Relations of the Benelux Countries with Russia: Between Rhetorical EU Engagement and Competitive Business Interests", Journal of Contemporary European Studies, 19, p. 240.

- Christou, 2011. "Bilateral Relations with Russia and the Impact on EU Policy: The Cases of Cyprus and Greece”, Journal of Contemporary European Studies, 19, p. 229. 
- Council of the European Union, 2014. "Crimea: EU Extends Restrictions in Response to Illegal Annexation”, Press Release, 469/15, www.consilium.europa.eu/en/workarea/downloadasset.aspx?id=15519 (Accessed 13.06.2015).

- Council of the European Union, 2015. Press Release, $3505^{\text {th }}$ Council Meeting, Presse 114, PR CO 13, Brussels, http://www.consilium.europa.eu/en/press/press-releases/2015/06/19-crimea-eu-extendsrestrictions-illegal-annexation/ (Accessed 13.06.2015).

- David, 2011. “A Less than Special Relationship: The UK's Russia Experience”, Journal of Contemporary European Studies, 19, p. 209.

- David, Gower, Haukkala, 2011. "Introduction: The European Union and Russia”, Journal of Contemporary European Studies, 19, p. 183.

- Delcour, 2005. “L’Union Européenne et la Russie: Les Politiques Communautaires, Pierre Angulaire du Partenariat”, in Helly and Petiteville (Eds.), L'Union Européenne, Acteur International. L'Harmattan, Paris, p. 156.

- European Commission, Directorate-General for Trade. "European Union. Trade in Goods with Russia", http://rade.ec.europa.eu/doclib/docs/2006/september/tradoc_113440.pdf (Accessed 14.06. 2015).

- European Commission. "Treaties Office Database", http://ec.europa.eu/world/agreements/searchByCountryAndContinent.do? countryId=3853\&countryName=R ussia (Accessed 14.06. 2015).

- European Commission, 2011. "EU-Russia Energy Dialogue. The First Ten Years: 2000-2010", http://ec.europa.eu/energy/international/russia/dialogue/dialogue en.htm (Accessed 13.06. 2015).

- European Commission, 2013. "Roadmap. EU-Russia Energy Cooperation until 2050", http://ec.europa.eu/energy/en/topics/international-cooperation/russia (Accessed 13.06. 2015).

- $\quad$ European Commission, 2013. "Enhancing Business Ties with Russia through Regulatory, Business and Tourism Cooperation", http://ec.europa.eu/growth/toolsdatabases/newsroomYcf/itemdetail.cfm?item id=1028\&title=Enhancing-business-ties-with-Russia-trhoughregulatory\%2C-business-and-toursim-cooperation (Accessed 14.06. 2015).

- European Union Newsroom. "EU Sanctions against Russia over Ukraine Crisis", http://europa.eu/newsroom/highlights/special-coverage/eu sanctions/index en.htm\#5 (Accessed 13.06. 2015).

- Eurostat. "EU28 imports of energy products from Russia, 2005-2013", http://ec.europa.eu/eurostat/statisticsexplained/index.php/File:EU28_imports_of_energy_products_from_Russia,_20052013 \%28EUR billion\%29.png (Accessed 15.06. 2015).

- Eurostat, 2014). "Main Origin of Primary Energy Imports, EU-28, 2002-2012 (\% of Extra EU-28 imports)", http://ec.europa.eu/eurostat/statisticsexplained/index.php/File:Main_origin of primary energy imports, EU28,_2002\%E2\%80\%9312_\%28\%25_of_extra_EU-28_imports\%29_YB14.png (Accessed 15.06. 2015).

- Grand, 2014. "La Russie, l'Occident et la Paix Froide”, Commentaire, 146, p. 293.

- Haukkala, 2015. "From Cooperative to Contested Europe? The Conflict in Ukraine as a Culmination of a Long-Term Crisis in EU-Russia Relations”, Journal of Contemporary European Studies, 23, p. 31.

- Laïdi (2008). La Norme sans la Force. L'Enigme de la Puissance Européenne. Presses de Sciences Po, Paris.

- Lefort, 2014. “La Crise Ukrainienne ou le Malentendu Européen”, Politique Etrangère, 2, p. 120.

- Makarychev, 2014. "Russia and/versus the EU: From Post-Political Consensus to Political Contestations", L'Europe en Formation, 374, p. 36.

- Maternovsky, 2009. "Ruble Gains versus Dollar 'Inevitable', Zadornov Says (Update1)”, Bloomberg, http://www.bloomberg.com/apps/news?pid=newsarchive\&sid=aPzxsrEg7GUc (Accessed 15.06. 2015).

- Sakwa, 2015. "The Death of Europe? Continental Fates after Ukraine”, International Affairs, 91, pp. 558559.

- Simao, 2011. "Portuguese and Spanish Relations with Moscow: Contributions from the EU's Periphery to the CFSP", Journal of Contemporary European Studies, 19, p. 222.

- Suremain, 2014. “L’Ukraine en Crise, l’Europe Fracturée”, Commentaire, 148, p. 745.

- Tchernega, 2014. "Pourquoi Russie et Union Européenne Doivet Coopérer en Ukraine", Politique Etrangère, 2, p. 107.

- $\quad$ Thom, 2014. “Poutine. L'Heure de Vérité”, Commentaire, 147, p. 503. 
- Timmins, 2004. "Coping with the New Neighbours: The Evolution of European Union Policy towards Russia”, Perspectives on Politics and Society, 5, pp. 358-359.

- Timmins, 2011. "German-Russian Bilateral Relations and EU Policy on Russia: Between Normalisation and the 'Multilateral Reflex”, Journal of Contemporary European Studies, 19, p. 197. 